\title{
Кучеренко А.В. \\ Актуальность кантовской этики в условиях назревших проблем современной цивилизации
}

ГОАУ ВО Курской области «Курская академия государственной и мунищипальной служсбь»»

(Россия, Курск)

doi: 10.18411/lj-07-2021-189

\section{Аннотация}

Вся совокупность проблем современной цивилизации, связанных с общественной жизнью, сосуществованием природы и общества, развитием научного знания, так или иначе, находит свое основание в области этических норм, которым руководствуется либо отдельный человек, либо то или иное сообщество, включая этносы, нации и государства. Нерешенные проблемы в области этики проецируются во все сферы человеческой деятельности. Этика Канта находится в ряду великих этических учений.

Ключевые слова: общество, этика, проблема, разум, политика.

\section{Abstract}

The whole set of problems of modern civilization related to social life, the coexistence of nature and society, the development of scientific knowledge, one way or another, finds its foundation in the field of ethical norms, which are guided either by an individual or a particular community, including ethnic groups, nations and states. Unsolved problems in the field of ethics are projected into all spheres of human activity. Kant's ethics is among the great ethical teachings.

Keywords: society, ethics, problem, reason, politics.

Этика Канта непосредственно связана с прошлым, настоящим и будущим общечеловеческой истории. Пока имеют место межличностные отношения, и существует общественная жизнь, проблемы нравственности всегда будут находиться в центре внимания человека и общества. Кант создает свое оригинальное этическое учение, не потерявшее своего актуального значения. Как справедливо отмечает Я.А. Слинин «Этика Иммануила Канта весьма злободневна для нас» [1, с. 154].

Bce глобальные проблемы современности, касающиеся вопросов межгосударственных отношений, системы «человек - общество» и «общество природа», имеют в своем основании еще не нашедшие своего решения противоречия в этической области.

Сегодня, как это ни странно звучит, главную угрозу представляет блестящее достижение человеческого разума, связанное с открытием атомной энергии. Оно содержит возможности использования ее как во благо, так и во вред человеку. В связи с этим обратимся к недавней истории. США оказалась единственной страной, применившей атомное оружие против мирного населения. В 1945 г. звучит речь главы ЦРУ А. Далласа на конгрессе США, а в 1948 г. она переходит в его директиву («план Далласа»), определяющую политику США, направленную на скрытое моральное разложение населения СССР (сегодня уже России). Впоследствии этот план детализирован и во многом реализован в «Гарвардском проекте». Сразу же после 2-й мировой войны США вынашивало агрессивные планы нападения с помощью массированной атомной бомбардировки СССР, спасшего человечество от «коричневой чумы XX века» ценой огромных человеческих жертв. Лишь признание американским правительством в середине 1950-х годов возможности нанесения СССР равноценного ответного ядерного удара заставило отказаться от намеченного замысла. 
Вслед за этим в недрах Пентагона возникла и продолжает существовать концепция разжигания локальных военных конфликтов при вмешательстве во внутренние дела суверенных государств. Далее предусматривается искусственное создание в них состояния нестабильности, хаоса, а в результате переподчинения политики этих малых стран интересам США ради создания с их помощью пояса напряженности вокруг современной России (свежие примеры, - чеченская война, Грузия при Саакашвили, государственный переворот в Украине). Можно сказать, что США, маниакально стремясь к мировому господству с помощью силового давления и грязной дезинформации, продолжает оставаться очагом международных провокаций, цинично попирая все нормы международного права, прикрываясь демагогическими заявлениями об универсальных правах человека и высших нравственных ценностях, комично выставляя себя в роли учителя демократии.

На повестке дня все острее звучит проблема использования ядерного оружия международным терроризмом на почве политического, национального и религиозного экстремизма, предполагающего право на верховенство некоторой весьма сомнительной ценности, имеющей исключительное значение лишь для весьма узкого круга лиц.

К настоящему времени в философии сформировалась новая дисциплина «экософия» (согласно концепциям философов А. Нэсса и Ф. Гваттари), являясь синонимом «экологической мудрости». Дисциплина объединяет в себе все проблемы, связанные с провозглашением сохранения жизни человека в гармонии с окружающей природой, указывая на главную этическую ценность, - гармоничное сосуществование разнообразных форм жизни, тогда как ограниченный и дикий хищнический потребительский антропоцентризм уходит в прошлое. Осознание, что нельзя рубить сук, на котором сидишь, пришло к человечеству лишь после создания множества противоречий между преследуемой им ближайшей выгодой и непредвиденными отдаленными последствиями, гибельными для самого же человека. В частности, это касается интенсивной химизации сельского хозяйства, создания генномодифицированных продуктов, поспешного использования малоизученных лекарственных средств, синтезирования используемых в быту и на производстве токсичных химических соединений и т.д. Погоня за ближайшей мелкой выгодой подталкивает отдельных аморальных предпринимателей, экономящих на переработке ядовитых отходов своих предприятий, к их масштабному захоронению в мировом океане, подготавливая тем самым глобальную экологическую катастрофу. И здесь вновь в основе лежит этическая проблема.

В настоящее время в обществе все более оживленно обсуждаются этические вопросы, связанные с клонированием человека, генной инженерией, использованием стволовых клеток, опытами над человеческими эмбрионами, эвтаназией. По-прежнему остается острой проблема социальной несправедливости, значительного имущественного расслоения общества, запоздалой реакции власти на запросы общества, чиновничьего произвола.

Сегодня человечество прилагает усилия для решения проблем, переросших национальные и государственные рамки. Продолжается борьба за ограничение распространения ядерного оружия, его ликвидацию и запрет на производство при создании ненасильственного мира на основе взаимных договоренностей с учетом уважения суверенитетов и равноправного сотрудничества. Требуется укрепление международных связей в борьбе с транснациональной преступностью и наркотрафиком. Научный потенциал передовых стран объединяется для создания термоядерного реактора и мирного освоения космоса. Ведется борьба медицинского сообщества с наследственными болезнями, раком, СПИДом и иными тяжелыми заболеваниями, например, с коронавирусом.

Все это, так или иначе, выводит нас на ключевой вопрос об универсальных правах человека (вне национальной и государственной принадлежности), основанных 
на универсальных нравственных ценностях, рассмотрение которых находилось в центре внимания Канта, возвысившего практический разум над теоретическим. Если теоретический, по мнению Канта, направлен на познание законов природы, то практический, ставя во главу угла этику, предполагает переподчинение полученных теоретическим разумом знаний этическим ценностям, что сегодня звучит для нас более чем актуально, - жизненно необходимо.

Современная цивилизация насыщена неразрешенными проблемами, связанными с деформацией положительных этических норм во всех сферах ее жизнедеятельности (политической, идеологической, экономической, религиозной, национальной...) с учетом их взаимовлияния. Общественный организм не только имеет их подобно злокачественным образованиям, но и продолжает накапливать, что в результате приводит к нагнетанию и всплескам общественного недовольства, a также последующим социальным потрясениям, зачастую сопровождаемым кровопролитиями. В эту неспокойную область можно отнести нерешенные проблемы, связанные с созданием справедливого государственного устройства и установлением взаимоприемлемых норм международных отношений, межнациональными и межконфессиональными конфликтами, способами манипулирования общественным сознанием и информационными войнами, грязными технологиями на выборах, неэффективными способами борьбы с разнообразными формами преступности и т. д. Уже само понятие пре-ступности предполагает пере-ступание за границу некоторой моральной нормы, в результате чего наносится значительный ущерб имуществу, здоровью и достоинству граждан, обществу и государству. Насколько разумны и справедливы существующие законы, почему законодательство находится в постоянном процессе синергетической трансформации, составляет совершенно особую тему для разговора.

Предельно остро стоит вопрос о сущности и границах индивидуальной свободы, установления ее разумных пределов, противоречиво сочетающих либеральные ценности с идеей социальной справедливости.

Можно сказать, что пока существует общественная жизнь, постоянно будут иметь место, накапливаться и находить формы разрешения этические проблемы, связанные с процессом поиска гармонии между проявлениями свободы в разнообразных формах воли субъекта исторического действия, существующей в категориях индивидуального, особенного, общего и всеобщего.

Все более обостряется вопрос о светском характере государства на фоне нарастающего укоренения религиозного мировоззрения и возрастания роли церкви с ее настойчивыми попытками внедрения богословского учения в образовательный процесс, основанный на последних научных достижениях, в принципе исключающих существование в мире чего-либо сверхъестественного.

В связи с этим неустойчивым и подвижным состоянием общественного организма, как в России, так и на мировой арене можно считать весьма злободневным вопрос об освещении накопившихся социальных противоречий в области этики с позиций всемирно известных этических учений ради лучшего понимания современного состояния общества и определения дальнейших перспектив его развития. В ряду таких этических учений кантовское представляет совершенно особый интерес, поскольку затрагивает наши познавательные возможности в областях теоретического и практического (этического) разума (связанного с богословием), осуществляет непосредственный перевод нравственных ценностей в область правовых норм, предлагает вариант решения вопроса о способе устранения разногласий между религиозными конфессиями. В исторической перспективе оно определяет конечное гармоничное состояние вечного мира между народами. Кантовская этика касается раскрытия сущности человеческой свободы, устанавливает общечеловеческие 
этические ценности и указывает путь к определению их содержания, рассматривает связь этики и религии.

Но не все так однозначно и просто, когда всего лишь только само обращение к великому этическому учению способно помочь нам исчерпывающе ответить на все интересующие нас вопросы и создать инструкции по созданию эффективных способов решения всего разнообразия назревших социальных проблем. Однако, оно достаточно верно определяет основу построения нравственных взаимоотношений на всех уровнях и поэтому дает тот прочный фундамент, опираясь на который оказывается возможным сознательно выстраивать пирамиду справедливых отношений между субъектами разнонаправленных воль с учетом их частных, общих и всеобщих значений.

Раскрывая содержание кантовской этики, В.Ф. Асмус отмечает, что основу нравственности Кант предлагает искать и определять a priori вне каких-либо эмпирических условий. Отсюда, отмечает В.Ф. Асмус, моральный закон в человеке априорен и познается a priori. Нравственный закон оказывается совершенно формальным (отстраненным от конкретных условий общения) и этот формализм этики Канта направлен против всякой попытки обосновать нравственность эмпирически. Попытки вывести моральный закон эмпирически, считает Кант, невозможно с помощью априорных понятий спекулятивного разума. Само понятие «спекулятивного» для Канта есть синоним «теоретического», то есть направленного на познание объектов природы, по сути трансцендентных для него, и потому недоступных для исчерпывающего отражения их содержания в понятиях. Практический же разум, направленный на познание морального закона, способен проникать в ноуменальную область и постигать совокупность всеобщих моральных норм, поскольку в противном случае человек был бы освобожден от ответственности за свои поступки при их нарушении, - ведь он не имел бы о них никакого представления.

По Канту, считает В.Ф. Асмус, человек подчинен собственному и, тем не менее, всеобщему законодательству, где закон имеет одно и то же определяющее основание для индивидуальной воли, - он «во мне» в такой же мере, как и в каждом другом. Долг следовать всеобщим моральным нормам включает в себя принуждение воли со стороны разума, требующего отказа от удовольствий, проистекающих из себялюбия. Человек имеет в себе цель достижения предельной степени нравственного совершенства, тогда как все остальное лишь призвано сопутствовать этому.

Кант отмечает, что «некоторые логики предполагают в логике психологические принципы. Но вносить в логику такие принципы столь же бессмысленно, как черпать мораль из жизни» [2, с. 429]. Моральные нормы, считает Кант, нельзя выводить из практики эмпирических отношений, основанных на переплетении и столкновении реальных интересов, в результате чего складывалось бы одобрение или осуждение того или иного поступка. Наоборот, логику построения отношений определяют моральные принципы, лежащие до них в априорной области. При определении оценки по поводу того или иного конкретного случая поведения как морально хорошего или плохого люди постоянно ссылаются на универсальные нормы априорного морального закона или некоторые общепринятые нормы.

«Нельзя придавать теоретической идее объективную реальность или доказывать ее, - пишет Кант, - за исключением идеи свободы, именно потому, что последняя есть условие морального закона, реальность которого есть аксиома. Доказывать реальность идеи бога можно лишь из этой [реальности нравственного закона]...» [3, с. 492]. Фраза о том, что свобода выступает «условием морального закона» требует осмысления. Можно определить ее смысл двояко, - свобода выступает условием существования морального закона или моральный закон есть условие возможности свободы воли. Если брать свободу в более широком смысле, например, имея в виду еще и свободу продуктивного воображения, то она приобретает более широкий трансцендентальный смысл (поскольку присутствует и 
в области познания объектов природы), не ограниченный этикой. Но зато в этике свобода колеблется («стоит на распутье») между жесткими альтернативами служения либо себялюбивым склонностям, либо общезначимым нормам, попадая в некоторое подобие энергетической ловушки с двумя центрами ее притяжения.

$$
* * *
$$

1. Слинин Я.А. Этика Иммануила Канта / Ю.В. Перов, К.А. Сергеев, Я.А. Слинин. Очерки истории классического немецкого идеализма. СПб.: Наука.- 2000. - С. 154-206.

2. Кант И. Логика. Пособие к лекциям / И. Кант // Трактаты. - СПб.: Наука - 2006. - С. 425-534.

3. Кант И. Логика. Пособие к лекциям / И. Кант // Трактаты. - СПб.: Наука - 2006. - С. 425-534.

\section{Петров И.Ф. Идентификация личности}

Академия маркетинга и сочиально-информационньх технологий (Россия, Краснодар)

doi: $10.18411 / \mathrm{j}-07-2021-190$

\section{Аннотация}

В статье показывается, что человек может быть субъектом социальных отношений только в той мере, в какой его деятельность сливается с деятельностью других людей, входящих в историческую общность или устойчивую ассоциацию людей. Другими словами, индивид является истинным субъектом социальных отношений, создателем реальности и активным началом только потому, что таким субъектом является сообщество, в которое он входит и интересами которого объективно детерминирована его деятельностью. Таким образом, идентификация - это не свободный, а социально обусловленный выбор принадлежности к определенной группе. субъект.

Ключевые слова: идентификация, общество, индивид, личность, человек,

\section{Abstract}

The article shows that a person can be a subject of social relations only to the extent that his activity merges with the activities of other people who are part of a historical community or a stable association of people. In other words, an individual is a true subject of social relations, the creator of reality and an active principle only because such a subject is the community into which he enters and whose interests are objectively determined by his activity. Thus, identification is not a free, but a socially conditioned choice of belonging to a certain group.

Keywords: culture, personality, society, person, needs, cultural needs.

По мысли К. Маркса, социальные отношения не сводятся к деятельности отдельных людей, и человек не является единственным субъектом социальных отношений. Представляя противоположность природы и общества, как противоположность объекта и субъекта, он полагал, что «рассматривать общество как один - единственный субъект, значит, рассматривать его неправильно, умозрительно» [3, с. 720]. Следует отметить, что наряду с обществом и личностью исторические общности и ассоциации людей должны рассматриваться как субъекты социальных отношений.

При этом, человек может быть субъектом социальных отношений только в той мере, в какой его деятельность сливается с деятельностью других людей, входящих в историческую общность или устойчивую ассоциацию людей. Другими словами, индивид является истинным субъектом социальных отношений, создателем реальности 